\title{
メチルイソプロピルケトン-(カルボニル $\left.-{ }^{14} \mathrm{C}\right)$ の合成
}

\author{
岩田典子, 稲本直樹, 森川尚威, 島村 修
}

(東京大学理学部化学教室)

(昭和 36 年 5 月 9 日 受理)

$\alpha$-アセチルイソブチロフェノンの転位反応機構

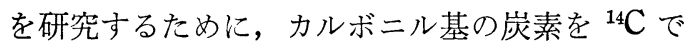
標識したメチルイソプロピルケトンを合成した。 合成の概要はつぎのとおりである。

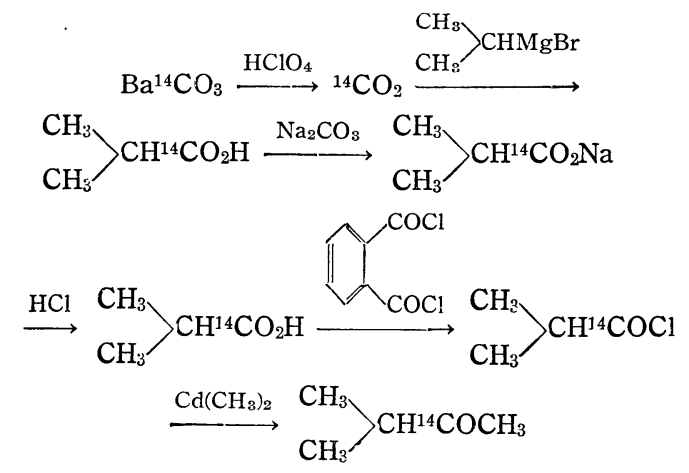

炭酸バリウム ${ }^{14} \mathrm{C}$ か過塩素酸により二酸化炭 素- ${ }^{14} \mathrm{C}$ を発生させ，グリニヤール反応によってイ ソ酪酸-(カルボキシル- ${ }^{14} \mathrm{C}$ ) を合成する。これを ナトリウム塩として取り出し, 塩化水素ガスでふ たたび遊離の酸とし，塩化フタロイルにより塩化 イソブチリルー(カルボニル- $\left.{ }^{14} \mathrm{C}\right)$ とする。つぎに ジメチルカドミウムでメチル化して, メチルイソ プロピルケトンー(カルボニル- $\left.{ }^{14} \mathrm{C}\right)$ を得た。炭酸 バリウム ${ }^{14} \mathrm{C}$ からの放射化学的収率は $16 \%$ 程度 と思われる。

この合成にあたって留意した点はカルボニル標 識であるので, 多少実験操作は複雑であり, 収率 はかならずしもよくないが，生成物を純粋に得ら れる点を重視してこの種の合成には初めての試み として上述の反応経路を用いた。窒素気流中の操 作をもっぱら用い，副生成物をできるだけ生成さ せぬように注意し，とくに放射化学的収率を高め
るため, ジメチルカドミウムを，合成したままの 不純物を含む溶液中で反応を行なわせず，窒素気 流中で蒸留し, できるだけ純粋なジメチルカドミ ウムを単離して, これを塩化イソブチリルー(カル ボニル-14C) とほぼ当量反応させた。

また, 合成したメチルイソプロピルケトンの精 製は, 予備実験のときに, コンセントリック精密 分留装置によって, 留分の元素分析值がメチルイ ソプロピルケトンに一致するまで蒸留をくり返し 行ない, それと同様にコンセントリック精密分留 装置で蒸留を行なって，蒸留のたびごとに無標 識のメチルイソプロピルケトンを担体として加え た。なお, 予備実験のさい, 精密分留によって得 られたメチルイソプロピルケトンは, ガスクロマ トグラフィによっても純粋なものであることが確 認された。

\section{実 験 $の$ 部}

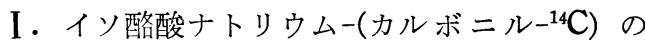
合成

1. 臭化イソプロピルマグネシウム

イソプロピルアルコールから三臭化リンによっ て合成した臭化イソプロピル $\left.{ }^{1}\right) 7.4 \mathrm{~g}(60 \mathrm{mmol})$ とマグネシウムリボン $1.6 \mathrm{~g}(66 \mathrm{mmol})$ とから, 既報 ${ }^{2}$ の臭化フェニルマグネシウムの調製と同様 にして，臭化イソプロピルマグネシウムを合成す る。Gilman の方法沙により，グリニヤール試薬 を定量したところ， $1.38 \mathrm{mmol} / \mathrm{ml}$ のもの $35 \mathrm{ml}$ を得たので, 全体で約 $49 \mathrm{~m} \mathrm{~mol}$ の収量となり, 収率は約 $80 \%$ である。

2. 二酸化炭素 ${ }^{14} \mathrm{C}$ 
炭酸バリウム ${ }^{14} \mathrm{C} 189.4 \mathrm{mg}(2.0 \mathrm{mc})$ と無標識 炭酸バリウム $797.9 \mathrm{mg}$ (全体で $987.3 \mathrm{mg}, 5.0$ $\mathrm{m} \mathrm{mol})$ から, $60 \%$ 過塩素酸 $35 \mathrm{ml}$ を用いて, 既報 ${ }^{2)}$ どおりして二酸化炭素- ${ }^{14} \mathrm{C}$ を発生させ る。

3. イソ酪酸-(カルボキシル- $\left.{ }^{14} \mathrm{C}\right)$

1. で合成したグリニヤール試薬 $4 \mathrm{~m} l(5.5 \mathrm{~m}$ $\mathrm{mol})$ と乾燥エーテル $14 \mathrm{ml}$ をグリニヤール反応 装置に入れ， 既報2と同様にして反応させ， $2 \mathrm{~N}$ 塩酸 $7 \mathrm{ml}$ を加えて, イソ酪酸ー(カルボキシルー $\left.{ }^{14} \mathrm{C}\right)$ を得る。

未反応の二酸化炭素 $-{ }^{14} \mathrm{C}$ を水酸化ナトリウムに

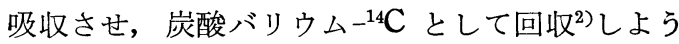
としたが，わずかに炭酸バリウムの白沈が生ずる 程度で, ほとんど未反応の二酸化炭素- ${ }^{14} \mathrm{C}$ は存 在しなかった。

なお，予備実験の結果から炭酸バリウムからの 収率は約 $86 \%$ と考えられる。

4. イソ酪酸ナトリウムー $\left(\right.$ カルボニル $\left.-{ }^{14} \mathrm{C}\right)$

グリニヤール反応混合物を塩化ナトリウム $13 \mathrm{~g}$ を入れたソックスレー液体抽出器に移し, 反応容 器を水 $40 \mathrm{ml}$ で洗い, さらにエーテルで洗って ソックスレー抽出器に入れ, 塩析しつつエーテル で約 10 時間抽出する。この抽出したエーテル溶 液をほかのソックスレー液体抽出器に移し, 無水 炭酸ナトリウム $350 \mathrm{mg}$ を水 $30 \mathrm{ml}$ に溶かした ものを加え，かきまぜてアルカリ性 $(\mathrm{pH}$ 約 8.4$)$ としてイソ酪酸ー(カルボキ シル- $\left.{ }^{14} \mathrm{C}\right)$ をナトリウム塩 として水層に移す。これを 赤外線憕で外部から加熱し てェーテルを駆出したの ち，あらたにエーテルを加 えて約 7 時間副反応物を抽 出してのぞく。受器をかえ て,さらに 5 時間抽出した のち, 水層上のエーテルを のぞき, 赤外線燈で完全に エーテルを駆出する。水溶
液を蒸発皿に移し, $100^{\circ} \mathrm{C}$ のグリセリン浴上で蒸 発乾固する。かくして得られたイソ酪酸ナトリウ ムー-(カルボニルー $\left.{ }^{14} \mathrm{C}\right)$ をデシケータ中に保存する。 つぎに，無標識イソ酪酸 $502.4 \mathrm{mg}$ を無水炭酸 ナトリウム $340 \mathrm{mg}$ の水溶液と作用させ, アルカ リ性であることを確かめ，この溶液の半分をイソ 酪酸ナトリウム $-\left(\right.$ カホホニルー $\left.{ }^{14} \mathrm{C}\right)$ を蒸発乾固さ せた蒸発皿に入れ, 同様な操作で蒸発乾固しデシ ケーター中に保存する。この操作を残り半分の無 標識イソ酪酸ナトリウムの水溶液で繰返し, でき るだけ放射能を集収する。

II. 塩化イソブチリル-(カルボニル- $\left.{ }^{14} \mathrm{C}\right)$ の合 成

1. イソ酪酸-(カルボキシルー $\left.\left.{ }^{14} \mathrm{C}\right)^{4}\right)$

図の J 塩化ナトリウム $850 \mathrm{mg}(14.5 \mathrm{~m} \mathrm{~mol}$, 使用した炭酸ナトリウム $6.5 \mathrm{~m} \mathrm{~mol}$ に対し約 12 $\%$ 過剩) を, I に濃硫酸 $15 \mathrm{ml}$ を入れる。 H, I, $\mathrm{J}$ 内を窒素ガスで置換したのち， $1 \times 10^{-2} \mathrm{mmHg}$ の真空にし, コック $1, \mathrm{~m}$ を閉じ， $\mathrm{H}$ を液体窒素 で泠却し, 徐々に濃硫酸を滴下して塩化水素を発 生させて Hに捕集する。

一方，Gに I-4 で合成したイソ酪酸ナトリウ ムー $\left(\right.$ カルボニル $\left.{ }^{14} \mathrm{C}\right)$ を入れ，その上をおおうよ らにガラス綿を入れる。G を約 2 時間 $130^{\circ} \mathrm{C}$ の グリセリン浴に浸し, ポンプでひいて完全に乾燥 する。

コック $\mathrm{a}, \mathrm{b}, \mathrm{c}, \mathrm{d}, \mathrm{e}$ 抢よび $\mathrm{i}$ を閉じ， 1 を開

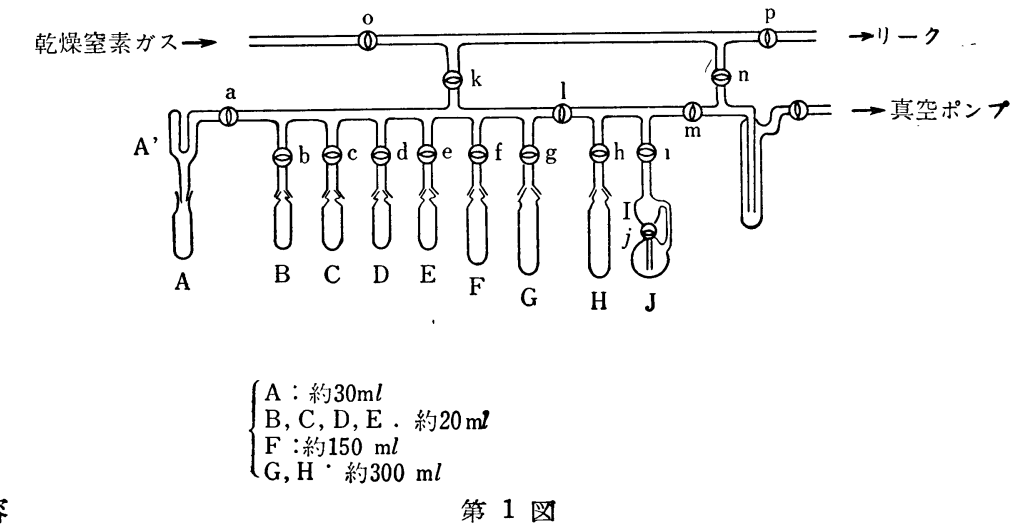


き, F, G, H (液体窒素で冷却)を $2 \times 10^{-4} \mathrm{mmHg}$ の真空にし，コック $\mathrm{k}$ を閉じる。塩化水素を $\mathrm{H} か$ ら $\mathrm{G}$ へ移し (H をドライアイスーアルコール冷却, $\mathrm{G}$ 液体窒素冷却)， $1, \mathrm{~g}$ を閉じ，冷却浴をはず して反応させる。 $\mathrm{g}$ を開き， $\mathrm{F}$ を液体窒素で冷却 して, 生成したイソ酪酸一(カルボキシルー $\left.{ }^{14} \mathrm{C}\right)$ な ぞを $\mathrm{F}$ に蒸留する。Fをドライアイスーアルコー ル冷却にかえ, Gを液体窒素で泠却し，Fから未 反応の塩化水素を $\mathrm{G}$ 一戻し, $\mathrm{g}$ を閉じ $\mathrm{G}$ の冷却浴 をはずして反応させる。ここに生じたイソ酪酸一 (カルボキシル ${ }^{14} \mathrm{C}$ ) を前と同様に蒸留する。こ の操作を 5 回以上繰返して, 次第に $\mathrm{G}$ を $100^{\circ} \mathrm{C}$ まで加熱し，イソ酪酸-(カルボキシルー $\left.{ }^{14} C\right)$ を十 分 $\mathrm{F}$ 一蒸留し, 最後に $\mathrm{F}$ から過剩の未反応塩化水 素などを分離し，f， g を閉じる。

2. 塩化イソブチリル-(カルボニル $\left.\left.-{ }^{14} \mathrm{C}\right)^{5}\right)$

図の $\mathrm{A}$ 亿塩化フタロイルを $5 \mathrm{~g}$ 入れ, 液体窒素 で冷却し, 塩化フタロイルを固化させたのち、コ ック a を開いて排気し， a を閉じ， A の冷却を はずし, 塩化フタロイル中に含まれていた気体を

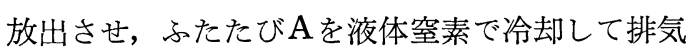
する。この脱ガスの操作を繰返したのち， $\mathrm{k}$ を閉 じ, $2 \times 10^{-4} \mathrm{mmHg}$ の真空下で $\mathrm{F}$ のイ酪酸-(カ ルボキシルー- ${ }^{14} \mathrm{C}$ ) を $\mathrm{A}$ に蒸留する。

コック $\mathrm{n}$ 閉じ， $\mathrm{k}$ 開き， $\mathrm{o}$ を徐々に開いて 窒素ガスでAを常圧にもどし，oを閉じ $\mathrm{p}^{*}$ を開 く。 $\mathrm{A}$ の上部のトラップ $\mathrm{A}^{\prime}$ をドライアイスーアル コールで $-50^{\circ} \mathrm{C}$ に冷却し, $\mathrm{A}$ を約 2 時間 $130^{\circ} \mathrm{C}$ に加熱し還流させる。a を閉じ，トラップ $\mathrm{A}^{\prime}$ の 冷却をのぞき，Aを液体窒素で冷却してトラップ $\mathrm{A}^{\prime}$ を加温する。 $\mathrm{a}, \mathrm{b}$ を開き, $1 \times 10^{-2} \mathrm{mmHg}$ の 真空にして $\mathrm{k}$ 閉じる。Bを液体窒素で，Aの上 部のトラップ $\mathrm{A}^{\prime}$ なたたびドライアイスーアルコ 一ルで泠却し, Aを徐々に温めて, 生成した塩化 イソブチリルー(カルボニルー $\left.{ }^{14} \mathrm{C}\right)$ を $\mathrm{B}$ に蒸留する。 $\mathrm{A}$ の上部のトラップ $\mathrm{A}^{\prime}$ はその間 $-40^{\circ} \sim-50^{\circ} \mathrm{C}$ に保ち, 不純物が一緒に蒸留されるのを防ぐ。

* コック p の先には $\mathrm{Mg}\left(\mathrm{ClO}_{4}\right)_{2}$ が接続している。
つぎに真空度を約 $2 \mathrm{mmHg}$ とし，Bをドライ アイスーアルコールの冷却にかえ，A を液体窒素

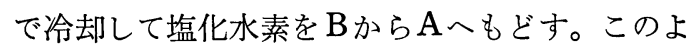
うにして得られた塩化イソブチリルー(カルボニル $\left.-{ }^{14} \mathrm{C}\right)$ の収量は $926 \mathrm{mg}(8.7 \mathrm{~m} \mathrm{~mol})$ で, グリニヤ 一ル反応の収率が $86 \%$ とすると, イソ酪酸-(カ ルボキシル- ${ }^{14} \mathrm{C}$ ) からの収率は $87 \%$ となる。

つぎの合成の目的により，無標識の塩化イソブ

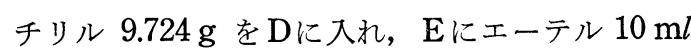
を入れて，これらの系を真空とし，それぞれ脱ガ スを行なったのち，高真空度にしてD中の一部を $\mathrm{A}$ 一蒸留する。一方, $\mathrm{B}$ 中の塩化イソブチリル (カルボニルー $\left.{ }^{14} \mathrm{C}\right)$ を $\mathrm{C}$ へ蒸留し，つぎに $\mathrm{A} に$ 加え た塩化イソブチリルを $\mathrm{B}$ 一蒸留し，さらにC $\mathrm{C}$ 移 す。この操作を 2,3 回繰返し, できるだけ $\mathrm{A} に$ 残 る塩化イソブチリルー(カルボニルー- ${ }^{14} \mathrm{C}$ ) の濃度を うすくする。最後に $\mathrm{E} 中 の エ ー テ ル を \mathrm{C} へ$ 移し, エーテル溶液としておく。（真空のままドライア イスーアルコールで冷却して一夜放置し,つぎの 反応にうつる)。

III. メチルイソプロピルケトンー(カルボニルー $\left.{ }^{14} \mathrm{C}\right)$ の合成

1. ジメチルカドミウム ${ }^{6}$

マグネシウムリボン $65 \mathrm{~g}(2.7 \mathrm{~mol})$ と臭化メチ ル7) $264 \mathrm{~g}(2.8 \mathrm{~mol})$ とから窒素気流中でエーテル を溶媒として臭化メチルマグネシウムを合成し， 既報 ${ }^{2)}$ 臭化フェニルマグネシウムと同様に窒素 気流中で口過して未反応のマグネシウムをのぞ き，Gilman の方法勇によって定量したところ， $1.26 \mathrm{~mol}$ であった。

このグリニヤール試薬を氷冷し，かきまぜなが ら同じく窒素気流中で塩化カドミウム* $119 \mathrm{~g}(0.65$ mol）を徐々に加える。冷却をのぞいてさらに約 15 時間還流させかきまぜつづける。グリニヤール 試薬の呈色反応 (Gilman's test) ) $^{8}$ を示めさなく なるまで十分反応させる。反応液は灰色のどろど ろしたものとなるが，それをそのまま窒素気流中

* 市販の水和物を $110^{\circ} \mathrm{C}$ 飞加熱して脱水乾燥した。 の。 
で蒸留し，留分をドライアイスーアルコールで冷 却して受ける。まず, $35^{\circ} \mathrm{C}$ でエーテルが留出し， そののちだらだらと $100^{\circ} \mathrm{C}$ くらいまで沸点があ がる。この留分を再蒸留すると，沸点 $100^{\circ}$ 。 $104.5^{\circ} \mathrm{C}$ のジメチルカドミウムを $68 \mathrm{~g}$ (グリニヤ ール試薬より $77 \%$ ) 得る。

これらの操作はすべて窒素気流中で行ない，ジ メチルカドミウムは窒素気流中にたくわえ*, $-20^{\circ} \mathrm{C}$ くらいに冷却, 結晶化して保存する。蒸 留中空気がはいると，爆発的に分解するし（油浴 温度 $160^{\circ} \mathrm{C}$ ), 常温でも空気にふれると分解して白 色固体を生ずる。精製したジメチルカドミウムは 無色透明の重い液体で強い刺激臭を有し, 鼻, の ど, 目を痛める。

2. メチルイソプロピルケトンー(カルボニ ル $\left.{ }^{14} \mathrm{C}\right)^{9), 10)}$

$200 \mathrm{~m} l$ の 3 つロフラスコに塩化カルシウム管 をつけた還流泠却器と滴下漏斗とガス導入管をつ け, 容器内を窒素ガスで置換したのち, 合成した ジメチルカドミウム $5.4 \mathrm{ml}(10.6 \mathrm{~g}, 75 \mathrm{mmol})$ と エーテル $50 \mathrm{~m} l$ とを入れる。II で合成した塩化イ ソブチリル-(カルボニル- ${ }^{14} \mathrm{C}$ ) (図の $\mathrm{C}$ の容器にエ ーテル溶液としてたくわえてある) をエーテル 30 $\mathrm{m} l$ で滴下漏斗に入れる。電磁式かきまぜ機でか きまぜながら, 窒素気流中で徐々に滴下し, 滴下 後約 $42^{\circ} \mathrm{C}$ の水浴で加温してかきまぜつづける。 約 20 分ののち鱗片状の沈殿が生じ, やがて白色 沈殿となる。約 15 時間かきまぜて, 上澄液にバ イルシュタインテストでもはや塩素が認められな くなったら泠却し, 希硫酸（濃硫酸 $6 \mathrm{ml}$ +水 40 $\mathrm{m} l$ ) を滴下して分解する。

エーテル層を分別し, 水層をソックスレー液体 抽出器でエーテル抽出し, エーテル溶液を前に分 別したものと一緒にし，10\%炭酸ナトリウム水溶 液で 2 回洗い, さらに水洗して無水硫酸ナトリウ ムで乾燥する。洗液は一括してソックスレー液体 抽出器でふたたびエーテル抽出し, エーテル溶液

*容器はすへて摺合わせを用い, 摺の部分にはシリコ ングリースを塗布する。
を水洗後無水硫酸ナトリウムで乾燥し, 前のエー テル溶液とともに，コンセントリック精密分留装 置でエーテルを留去し, 精密蒸留する。沸点 90 $107^{\circ} \mathrm{C}$ の留分約 $4 \mathrm{ml}$ をとり，コンセントリック 精密分留装置で再蒸留する。沸点 $93 \sim 97^{\circ} \mathrm{C}$ の留 分をとり, 残留物に無標識メチルイソプロピルケ トン ${ }^{11)}, 1.1987 \mathrm{~g}$ を加えて蒸留し, 同じ沸点の留 分をとり先の留分に加える。これを再蒸留し，沸 点 $94^{\circ} \mathrm{C}$ の留分をとり, 残留物に前回同様, 無標 識メチルイソプロピルケトン $1.5297 \mathrm{~g}$ を加えて 蒸留し, 同じ沸点留分をとり, 先の留分に加えて さらに蒸留する。この場合も前回同様にして無標 識メチルイソプロピルケトンを $1.6007 \mathrm{~g}$ 加えた。 最後にもう一度蒸留し, 沸点 $94^{\circ} \mathrm{C}$ の留分 4.7 $\mathrm{m} l$ (約 $3.8 \mathrm{~g}$ ) を得た。

IV. メチルイソプロピルケトンー(カルボニルー $\left.{ }^{14} \mathrm{C}\right)$ の比放射能の決定

合成したメチルイソプロピルケトンー(カルボニ

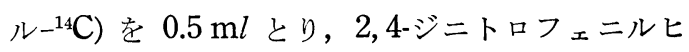
ドラゾンとしてとり出し, 含水エタノールから一 定計数率を示すまで再結晶をくり返す。

放射能の測定は，この結晶をV Van Slyke-Folch の湿式酸化法によって炭酸バリウム ${ }^{14} \mathrm{C}$ として無 限厚さで計数した。

その結果，合成したメチルイソプロピルケト ンー(カルボニル-14 C) の比放射能は 6.74士0.05 mc /mol であった。こ机は全放射化学的収率 $16 \%$ に 相当する。

\section{文献}

1) C. R. Noller, R. Dinsmore: "Organic Syntheses" Coll. Vol. II. p. 358 (1950)

2) 森川, 伊藤, 右田, 丹野, 島村: Radioisotopes, 8 , 246 (1956)

3) H. Gilman, P. D. Wilkinson, W. P. Fishel, C. H. Meyers: J. Am. Chem. Soc., 45, 156 (1923)

4) J. D. Cox, H. S. Turner: J. Chem. Soc., 3176(1950)

5) L. P. Kyrides: J. Am. Chem. Soc., 59, 206 (1936)

6) E. Kranse: Chem. Ber., 50, 1813 (1917)

7) H. J. Lucas, W. G. Young: J.Am. Chem. Soc., 
51, 2535 (1929)

8) H. Gilman, F. Schulze: J. Am. Chem. Soc., 47, 2002 (1925)

9) H. Gilman, J. F. Nelson: Rec. trav. chem. Pays-
Bas, 55, 518 (1936)

10) J. Cason: Chem. Rev., 40, 15 (1947)

11) F. C. Whitmore, W. L. Evers, H. S. Rothrock: “Organic Syntheses" Coll. Vol. II, p. 408 (1950)

\title{
The Synthesis of Methyl Isopropyl Ketone-(carbonyl- $-{ }^{14} \mathrm{C}$ )
}

\author{
By \\ Noriko IWATA, Naoki INAMOTO, Naotake MORIKAWA, Osamu SIMAMURA \\ (Dept. of Chem., Faculty of Science, Tokyo Univ.) \\ (Received May 9, 1961)
}

Methyl isopropyl ketone-(carbonyl-14 $\mathrm{C}$ ) was prepared as follows:

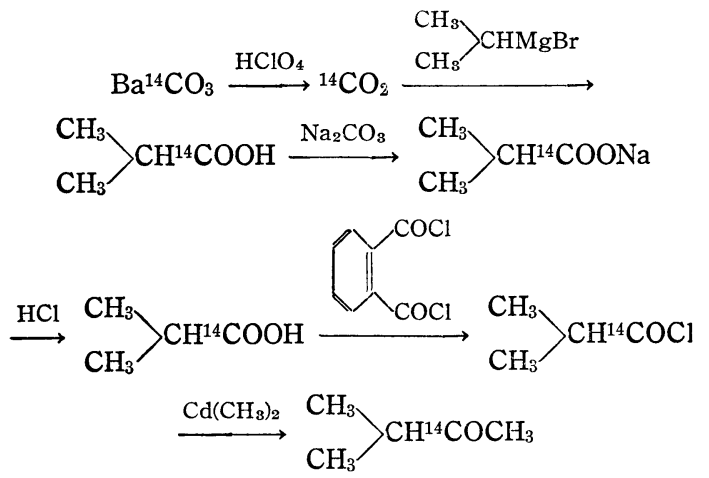

Carbon dioxide- ${ }^{-14} \mathrm{C}$ (from $987.3 \mathrm{mg}$ of labelled barium carbonate, $2.0 \mathrm{mc}$ ) was allowed to react with isopropyl magnesium bromide in ether and the product decomposed with $2 \mathrm{~N}$ hydrochloric acid $(7 \mathrm{ml})$. The mixture was extracted with ether (Soxhlet). The ether layer was mixed with aqueous sodium carbonate $(350 \mathrm{mg})$ and the ether evaporated off. The resulting alkaline solution was extracted with ether again and the aqueous layer was evaporated to dryness. The residual sodium isobutyrate-(carbonyl ${ }^{1-14} \mathrm{C}$ ) was diluted with non-labelled isobutyric acid (502.4 $\mathrm{mg}$ ) and sodium carbonate $(340 \mathrm{mg})$ and treated with hydrogen chloride to afford the free acid, which was distilled at a pressure of $2 \times 10^{-4}$ $\mathrm{mmHg}$ in a closed system. The labelled isobutyric acid was refluxed with phthaloyl chloride $(5 \mathrm{~g})$ and the product was distilled in a closed system at a pressure of $1 \times 10^{-2}$ $\mathrm{mmHg}$ to give isobutyryl chloride-(carbonyl$\left.{ }^{14} \mathrm{C}\right)$. This was diluted with the non-labelled isobutyryl chloride (9.724 g) in ether, and added under nitrogen to ether solution of dimethyl cadmium, which had been prepared from methyl magnesium bromide and cadmium chloride and distilled.

The mixture was refluxed for about $15 \mathrm{hrs}$, till no chlorine was detected in the ether layer, and added to dilute sulphuric acid, and the aqueous layer extracted with ether. The ether solutions were combined, washed with aqueous sodium carbonate and with water, and dried with anhydrous sodium sulphate. Repeated fractional distillations through a concentric column with occasional dilution with nonlabelled ketone (a total of $4.329 \mathrm{~g}$ ) gave $3.8 \mathrm{~g}$ of methyl isopropyl ketone (carbonyl$\left.{ }^{14} \mathrm{C}\right)$, b. p. $94^{\circ} \mathrm{C}(6.74 \pm 0.05 \mathrm{mc} / \mathrm{mol})$. The overall radiochemical yield was $16 \%$. 